\title{
Duckweed in Irrigation Water as a Replacement of Soybean Meal in the Laying Hens' Diet
}

\section{-Author(s)}

\section{Zakaria $\mathrm{HA}^{\prime}$}

Shammout MW"

The University of Jordan/School of Agriculture/Animal production Department/ Amman-11942/Jordan. E-mail: zakariah@ ju.edu.jo

" The University of Jordan/Water Energy and Environment Center/Amman-11942/ Jordan. E-mail: maisa_shammout@hotmail. com

\section{Mail Address}

Corresponding author e-mail address Dr. Hana A. Zakaria

The University of Jordan /School of Agriculture/Animal Production department/Amman-11942/Jordan. Phone: 00962798515389

Email: zakariah@ju.edu.jo

\section{ABSTRACT}

Water lentils (Duckweed [DW])(Lemna gibba), in irrigation ponds, was evaluated by replacing two levels of soybean meal (SBM) on performance and egg quality of laying hens of 54 weeks of age. A total of 72 white Lohmann laying hens were randomly allocated into 3 treatments with 6 replicates/treatment, 4 hens/replicate in a randomized complete block design. Treatments were: control group (DW0\%) with (SBM) as the main source of protein, T1 (DW10\%) and T2 (DW20\%), where duckweed replaced $10 \%$ and $20 \%$ of SBM for 9 weeks. No significant differences were observed among the dietary treatments in body weight change, feed conversion ratio, egg weight and mortality rate. Replacement with (DW20\%) decreased $(p<0.05)$ feed intake, egg laying rate and egg mass. The dry albuminin (DW10\%) decreased $(p<0.05)$ from 7 to 9 weeks and in the total period. Yolk pigmentation was highly $(p<0.001)$ improved by the replacement. Blood spots were increased $(p<0.05)$ with (DW20\%). Duckweed grown in good quality irrigation water can replace up to $10 \%$ of the SBM as a source of protein without adverse effects on hen performance and egg quality in addition to profitability.

\section{INTRODUCTION}

Duckweed (Lemna gibba), also called water lentil, is one of four species of plants that are monocotyledons belonging to the botanical family Lemnaceae, classified as higher plants, or macrophytes (Hilman \& Culley, 1978). Shammout \& Zakaria (2014) reported that these plants have an important role in purifying the irrigation water. Also it was used in water treatment as a natural bioremediation agent (Shammout et al., 2008). Goopy \& Murray (2003) confirmed that duckweeds can absorb nutrients from the waste and drained water forming biomass rich in protein, carbohydrates and pigments suitable for feeding domestic animals and fish. The use of duckweed as poultry feed has been recognized by many authors (Haustein et al., 1990b, 1992 and 1994; Islam et al., 1997; Leng, 1999; Rodriguez et al., 1999; and Samnang, 1999), even though the moisture content of duckweed can be the first limiting factor. Haustein et al., (1990b) suggested that higher quality duckweed (from 30\% to $40 \%$ protein, low ash, high carbohydrate) could substitute most of the soybean meal of up to $15 \%$ of the total intake and fish meal in diets of laying hens for good egg production, high yolk pigmentation and improved protein content of the egg, when duckweed is dehydrated to a dry meal. O'Neil et al., (1996) also found that there was an improvement in yolk pigmentation with the addition of up to $13 \%$ duckweed in the diet of laying hens. Duckweed also has a high concentration of trace minerals, such as potassium and phosphorus, and pigments, such as carotene and xanthophylls, which 
makes it a valuable dietary supplement for chicken (Haustein et al., 1990b, 1992 and 1994). The cost of animal feed generally accounts for $60 \%$ or more of the total production cost of raising poultry (Ministry of Agriculture, 2014), which is generally associated with high cost of important protein sources, such as soybean meal. This has increased the demand for an alternative local protein source for feeding (Shammout \& Zakaria, 2015b). Using local protein sources which have a similar quality level to that of soybean meal to replace the imported sources is one solution to reduce production costs. Lemna gibba is the Lemna species that has been recorded in water bodies in Jordan (AlEisawi, 1982). Other studies were conducted on this species in Jordan for the purpose of evaluation of the role of duckweed in purifying farm irrigation ponds as a natural water bioremediation agent (Shammout \& Zakaria, 2014, 2015b). However, the use of this species to replace part of the SBM in poultry diets scarcely received any attention, and there is no information currently available in Jordan about the use of duckweed as a protein replacement in the diet of laying hens.

Therefore, the present study is the first in Jordan and it was aimed out to utilize water lentils grown in irrigation water ponds as a source of protein by replacing percentages of soybean meal, with the optimum level of unconventional water lentils (duckweed) on the performance, egg production and egg quality of laying hens based on water quality, nutritive value of duckweed and cost.

\section{MATERIALS AND METHODS}

\section{Collection and preparation of duckweed samples and water quality analysis}

Duckweed was manually collected from irrigation water ponds in the central Jordan Valley; in particular, the farms of Ghor Kabid, Tal al-Ramleh, and Wadi alAbyad in Jordan by using pool skimmer nets. Collecting duckweed plants was an easy task since they form a floating mat with no structural unity. Fresh, wet duckweed was transported to the poultry laboratory in the School of Agriculture at the University of Jordan. Debris associated with the plants were removed, then the duckweed was air dried to approximately $40 \%$ moisture for 3 successive days; and then drying was completed in a forced air oven to around $6 \%$ moisture. The dried duckweed was stored at room temperature in porous knotted bags to be prepared for further analysis. Samples of the dried duckweed were analyzed for chemical composition AOAC(2005) prior to its use as a feed ingredient for DM (dry matter), crude protein, crude fiber, crude fat and minerals (Table 1a). On time of plant sampling, twenty water samples were collected for analysis to detect water quality, such as $\mathrm{Ca}, \mathrm{Mg}, \mathrm{K}, \mathrm{Cl}, \mathrm{SO}_{4}, \mathrm{PO}_{4}, \mathrm{NO}_{3}, \mathrm{Zn}, \mathrm{Pb}, \mathrm{Cd}$ and $\mathrm{Cu}$ (Table 1b), (Shammout \& Zakaria, 2015a). The study was conducted during the spring season, which is considered the vegetative period of the duckweed plant, and continued through the summer.

Table 1a - \% Nutrient composition of duckweed (Lemna gibba) and soybean meal

\begin{tabular}{|c|c|c|}
\hline Nutritive value & $\begin{array}{l}\text { Contents on dry matter } \\
(\%) \text { for duckweed }{ }^{1}\end{array}$ & $\begin{array}{l}\text { Contents on dry matter } \\
(\%) \text { for soybean meal }\end{array}$ \\
\hline Dry matter & 6.00 & 88.00 \\
\hline Water content & 94.00 & 12.00 \\
\hline Protein $(\% \mathrm{~N} \times 6.25)$ & 26.00 & 47.60 \\
\hline Crude fiber & 5.20 & 4.05 \\
\hline Ether Extract & 3.10 & 2.20 \\
\hline Energy (Kcal/Kg) & 2913 & 2337 \\
\hline$P$ & 0.86 & 0.62 \\
\hline K & 2.40 & 2.06 \\
\hline $\mathrm{Ca}$ & 4.30 & 0.27 \\
\hline $\mathrm{Mg}$ & 0.88 & 0.29 \\
\hline $\mathrm{Fe}$ & 0.20 & 0.17 \\
\hline $\mathrm{Cl}$ & 1.62 & 0.05 \\
\hline $\mathrm{Na}$ & 0.16 & 0.01 \\
\hline $\mathrm{Zn}$ & 0.008 & 0.006 \\
\hline $\mathrm{Mn}$ & 0.070 & 0.043 \\
\hline $\mathrm{Cu}$ & 0.002 & 0.002 \\
\hline
\end{tabular}

'Shammout \& Zakaria (2015b)

Table $\mathbf{1 b}$ - Average nutrients $\mathrm{mg} / \mathrm{l}$ in water in the presence of Duckweed (Lemna gibba) ${ }^{1}$

\begin{tabular}{lcc}
\hline Parameter & Water analysis $(\mathrm{mg} / \mathrm{l})$ & Allowed limits $\left(\mathrm{mg} / \mathrm{I}^{2}\right.$ \\
\hline $\mathrm{Ca}$ & 94 & 230 \\
$\mathrm{Mg}$ & 28 & 100 \\
$\mathrm{~K}$ & 15 & - \\
$\mathrm{Cl}$ & 330 & 400 \\
$\mathrm{SO} 4$ & 162 & 500 \\
$\mathrm{PO} 4$ & 4.60 & 30 \\
$\mathrm{Na}$ & 203 & 230 \\
$\mathrm{NO} 3$ & 21 & 70 \\
$\mathrm{Zn}$ & $<0.02$ & 5 \\
$\mathrm{~Pb}$ & $<0.01$ & 0.20 \\
$\mathrm{Cd}$ & $<0.002$ & 0.01 \\
$\mathrm{Cu}$ & $<0.01$ & 0.20 \\
\hline
\end{tabular}

'Shammout \& Zakaria $(2014,2015, a, b$,$) , JJordan standards 893, 2006$

\section{Birds, experimental design and diets}

The trial was conducted in open wire cage system housing at the University of Jordan/School of Agriculture which has a latitude of 32.009865 degrees, longitude of 35.872452 and an altitude of 1000 degrees. A total of seventy two white Lohmann laying hens of 54 weeks of age were randomly allocated to 3 treatments, 
each treatment consisted of 6 replicate cages as block design, with (4 birds/replicate cage), and fed three different diets in a randomized complete block design. Formulated diet was mainly based on corn and soybean meal. Dietary treatments were $\mathrm{DW}_{0}$ (control), where soybean meal was used as the only source of protein $(2716.6 \mathrm{Kcal} / \mathrm{Kg}) \mathrm{ME}, 47.6 \%$ protein, a layer diet containing $10 \%$ duckweed $\left(T_{1}\right)$, and $20 \%$ duckweed $\left(T_{2}\right)$ replacing the same percentage of soybean meal in the diet. The experimental diets were formulated in accordance with recommendations of the manual of the (Lohmann Management Guide, 2005) at the stage of production, taking into consideration the NRC (1994) requirements for laying hens as presented in (Table 2 ). The diet was fed in mash form and representative feed samples were ground for chemical analysis. Each cage $(40 \times 40 \mathrm{~cm})$ was provided with a feeder and a nipple drinker. Feed and water were supplied ad-libitum, and feeders between the different cages were separated by a wooden sheet to avoid mixing of dietary treatments. Each hen was weighed at the beginning of the trial, and 4 hens with similar average weight were housed in one cage. Hens were placed in the cages for one week before the trial started to adapt them to the feed and the environment, and no experimental data was collected at this stage. The experiment with data collection lasted for 9 weeks (54-63wks of age). The bird house was provided with a programmable lighting program with a day length of 10 hours, so an additional 6 hrs was provided during the experimental period. Inside house temperature was maintained at $20^{\circ} \mathrm{C}$ and $55 \%-60 \%$ relative humidity. The birds received identical care and management where sanitation and hygienic measures were followed during the experimental period. The experimental hens were treated according to standards for the humane treatment of animals following the guidelines of the Jordanian Society for the Protection of Animals (SPANA, issued in 2007).

\section{Data collection for production and egg parameters}

Feed consumption was recorded weekly by subtracting residual feed from the total feed provided and adjusted for mortality. Representative feed samples were collected and ground for chemical analysis AOAC(2005). Egg production was collected, weighed, classified and recorded daily with remarks on the cracked and blooded eggs. Calculations were based on a hen-day and hen-housed basis. Egg mass was determined by the equation (egg production $x$

Table 2 - \% Diet composition and content of dietary treatments

\begin{tabular}{|c|c|c|c|}
\hline Ingredient & Control (DW0) & T1(10\% of the Soybean meal) & T2(20\% of the Soybean meal) \\
\hline & \multicolumn{3}{|c|}{$54-63 w k s$} \\
\hline & \multicolumn{3}{|c|}{$\%$} \\
\hline Corn & 66.00 & 66.00 & 66.00 \\
\hline Soybean meal (47.6\% CP) & 22.00 & 19.80 & 17.60 \\
\hline Limestone (ground) & 9.20 & 9.20 & 9.20 \\
\hline Dicalcium Phosphate & 0.30 & 0.30 & 0.30 \\
\hline Concentrate $^{1}$ & 2.50 & 2.50 & 2.50 \\
\hline Duckweed (Lemna gibba) & 0.00 & 2.20 & 4.40 \\
\hline \multicolumn{4}{|l|}{ Nutrient Composition } \\
\hline $\mathrm{ME}(\mathrm{Kcal} / \mathrm{Kg})$ & 2716.60 & 2730.30 & 2744.01 \\
\hline Crude Protein & 15.73 & 15.29 & 14.86 \\
\hline DL-methionine & 0.41 & 0.39 & 0.39 \\
\hline Lysine & 0.87 & 0.89 & 0.93 \\
\hline Threonine & 0.61 & 0.58 & 0.55 \\
\hline Tryptophan & 0.20 & 0.19 & 0.17 \\
\hline Ether Extract & 2.86 & 2.92 & 2.98 \\
\hline Crude Fiber & 2.55 & 2.83 & 3.11 \\
\hline $\mathrm{Ca}$ & 4.04 & 4.16 & 4.28 \\
\hline P- nonphytate & 0.39 & 0.40 & 0.41 \\
\hline $\mathrm{Na}$ & 0.17 & 0.17 & 0.17 \\
\hline Choline Chloride mg/kg & 40.00 & 40.00 & 40.00 \\
\hline Cost price(JD)/ ton ${ }^{2}$ & 243.42 & 237.92 & 232.42 \\
\hline
\end{tabular}


egg weight). Layers were weighed individually every two weeks until the termination of the experimental period for estimation of body weight changes (Abudabos, 2011). Feed efficiency per dozen of eggs was determined by calculating the ratio between feed consumed (g) and total eggs produced (g) over a period of time. Hen mortality was recorded daily, and feed intake and egg production were corrected for mortalities.

\section{Measurements of egg quality}

Samples of 18 eggs/treatment (3/replicates) were randomly collected biweekly for external and internal quality parameters by separating, weighing and determining egg components ( $\%$ wet and dry albumin, yolk and shell) after drying at $50^{\circ}-55^{\circ} \mathrm{C}$ for 48hrs. Separation of egg components and their weight measurements were in accordance with Chowdhury (2000). Eggshell thickness was measured by shell thickness micrometer (Griffen \& Goerge Ltd, Japan) as the mean value of three locations on the egg. Haugh unit score was determined using the methods of Haugh (1937), which measures the height of the albumin and calculates the Haugh unit based upon egg weight using tripod micrometer height gauge, following the equation:

Haugh units $=100 \mathrm{log}$ (albumin height $(\mathrm{mm})+7.57$ 1.7 egg weight $0.37(\mathrm{~g})$.

Egg yolk color score was determined by comparing with the 15-point Roche Yolk color fan (F, HoffmannLa Roche and Co. Ltd. Basic, Switzerland).

\section{Statistical Analysis}

Data was analyzed as a randomized complete block design. There were 3 replicate pens (4birds/pen) with 3 dietary treatments. The treatment effects were evaluated as a one-way repeated measure (ANOVA) using the MIXED procedure in SAS (Version 9.4, 2013) with dietary treatments as the main source of variation among measured parameters. Pair wise comparisons were used to estimate significance of differences using PDIFF option of least square means (LSMEANS). Differences were considered significant where $(p<$ 0.05), unless otherwise specified. Pen means were used as the experimental units for all variables.

\section{Economic Assessment}

Economic assessment was carried out using price of feed ingredients at the time the trial was carried out to compare the cost of the different treatments when levels of soybean meal were replaced by the duckweed plant.

\section{RESULTS}

\section{Duckweed (Lemna gibaa) and water quality analysis}

The nutritional values of the duckweed plants were determined according to the standard methods of AOAC (2005). Fresh duckweed samples contain approximately 94\% water and 6\% DM. The average nutritive values on a dry matter basis are shown in (Table 1a), (Shammout \& Zakaria, 2015b). The analyzed water quality parameters were within the allowed limits set forth in the Jordanian Standard (JS 893/2006) for irrigation. The different minerals, such as $\left(\mathrm{Ca}, \mathrm{Mg}, \mathrm{K}, \mathrm{Cl}, \mathrm{SO}_{4}\right.$, and $\left.\mathrm{NO}_{3}\right)$, and the heavy metals $(\mathrm{Zn}, \mathrm{Cd}, \mathrm{Pb}$ and $\mathrm{Cu})$, were within the Ideal Detection Limits (Table1b). This applies also for water $\mathrm{pH}$ (8.1), EC (Electrical conductivity) $(1.62 \mathrm{mS} / \mathrm{cm}), \mathrm{BOD}_{3}$ (Biological Oxygen Demand)(Omg/l), and COD (Chemical Oxygen Demand)(Omg/l) (Shammout \& Zakaria, 2014, and 2015a,b).

\section{Laying performance}

The effect of replacing $10 \%$ and $20 \%$ of soybean meal with the same percentage of duckweed is shown in (Table 3). Feed intake decreased highly $(p=0.002)$ through the intervals of the experiment and during the total period when replacing $20 \%$ of soybean meal with the duckweed, while there was little impact on body weight change. Egg laying rate\% appeared to be reduced $(p<0.05)$ in hens receiving the $20 \%$ duckweed; the $10 \%$ group was very close to the control group, but it was highly evident $(p=0.001)$ in the 7-9 wk period and through the whole period of the experiment $(p<0.01)$. It is also evident that egg production decreased with age throughout the total period of the trial, which is a normal trend in laying hens. Feeding at $20 \%$ duckweed caused a decrease in the daily egg-laying rate, while it was variable with egg weight, since it was noted that through the 7-9 weeks of the trial it was higher than the $10 \%$ and the control.

Feed conversion ratio was almost the same in all the dietary treatment groups, and the difference was not significant. Egg mass was decreased $(p<0.05)$ by the $20 \%$ duckweed supplementation in each period of the trial. Control group and the $10 \%$ added group showed a higher egg mass than the $20 \%$ group. Mortality rate showed a trend $(p<0.05)$ in the $(7-9$ week) period in the $20 \%$ duckweed supplementation group, but not in other periods nor in the total period of the trial. 
Table 3 - Performance of laying hens fed diets containing 0\%, 10\%, or 20\% duckweed

\begin{tabular}{|c|c|c|c|c|c|c|}
\hline \multirow{2}{*}{ Period } & \multirow{2}{*}{ Parameter Measured } & \multicolumn{5}{|c|}{ Duckweed Inclusion Rate (\%) } \\
\hline & & DW0\% ${ }^{1}$ & DW10\% ${ }^{1}$ & DW20\% ${ }^{1}$ & $\mathrm{SEM}^{2}$ & $p$-Value \\
\hline \multirow[t]{7}{*}{$1-3 w k$} & Feed Intake (g/hen/day) & $124.24^{a}$ & $123.94^{a}$ & $96.63^{b}$ & 5.40 & $* *$ \\
\hline & Feed Conversion $(\mathrm{g} / \mathrm{g})^{3}$ & 1.74 & 1.71 & 1.57 & 0.08 & NS \\
\hline & Bodyweight (g/bird) & 1767.12 & 1711.33 & 1677.67 & 48.72 & NS \\
\hline & Egg Laying Rate (\%) & $87.76^{a}$ & $87.16^{a}$ & $75.46^{b}$ & 3.41 & * \\
\hline & Egg Weight (g) & 63.15 & 63.81 & 62.14 & 1.06 & NS \\
\hline & Egg Mass $(g)^{4}$ & $54.82^{\mathrm{a}}$ & $56.18^{a}$ & $46.91^{b}$ & 2.49 & * \\
\hline & Mortality Rate $(\%)^{5}$ & 1.39 & 1.39 & 1.39 & 1.35 & NS \\
\hline \multirow[t]{7}{*}{$4-6 w k$} & Feed Intake (g/hen/day) & $123.57^{a}$ & $116.72^{\mathrm{a}}$ & $101.66^{b}$ & 6.30 & * \\
\hline & Feed Conversion (g/g) & 1.88 & 1.78 & 1.42 & 0.14 & NS \\
\hline & Bodyweight (g/bird) & 1770.82 & 1711.68 & 1663.49 & 47.71 & NS \\
\hline & Egg Laying Rate (\%) & $85.74^{\mathrm{a}}$ & $82.93^{a}$ & $64.27^{b}$ & 5.83 & * \\
\hline & Egg Weight (g) & 64.82 & 63.43 & 63.02 & 0.84 & NS \\
\hline & Egg Mass (g) & $55.71^{\mathrm{a}}$ & $52.92^{\mathrm{a}}$ & $40.38^{b}$ & 4.01 & * \\
\hline & Mortality Rate (\%) & 0.19 & 4.16 & 6.94 & 3.02 & NS \\
\hline \multirow[t]{7}{*}{$7-9 w k$} & Feed Intake (g/hen/day) & $126.09^{a}$ & $117.02^{\mathrm{a}}$ & $88.10^{\mathrm{b}}$ & 6.48 & $* \star$ \\
\hline & Feed Conversion ( $\mathrm{g} / \mathrm{g}$ ) & 1.74 & 1.78 & 1.90 & 0.12 & NS \\
\hline & Bodyweight (g/bird) & 1761.20 & 1696.37 & 1645.37 & 49.15 & NS \\
\hline & Egg Laying Rate (\%) & $83.69^{a}$ & $76.34^{a}$ & $55.25^{b}$ & 5.36 & $=0.001$ \\
\hline & Egg Weight (g) & 64.15 & 62.77 & 66.14 & 1.32 & NS \\
\hline & Egg Mass (g) & $53.69^{a}$ & $47.96^{a}$ & $36.72^{b}$ & 3.78 & * \\
\hline & Mortality Rate (\%) & $1.39^{\mathrm{b}}$ & $2.77^{\mathrm{b}}$ & $16.67^{\mathrm{a}}$ & 3.53 & * \\
\hline \multirow[t]{7}{*}{$1-9 w k$} & Feed Intake (g/hen/day) & $124.24^{a}$ & $119.30^{\mathrm{a}}$ & $96.24^{b}$ & 4.97 & * \\
\hline & Feed Conversion (g/g) & 1.78 & 1.75 & 1.64 & 0.08 & NS \\
\hline & Bodyweight (g/bird) & 1765.34 & 1705.88 & 1664.25 & 46.44 & NS \\
\hline & Egg Laying Rate (\%) & $85.63^{a}$ & $82.32^{\mathrm{a}}$ & $64.91^{b}$ & 3.98 & $* *$ \\
\hline & Egg Weight (g) & 64.01 & 63.27 & 63.85 & 0.90 & NS \\
\hline & Egg Mass (g) & $54.75^{a}$ & $52.23^{\mathrm{a}}$ & $41.46^{b}$ & 2.84 & $=0.01$ \\
\hline & Mortality Rate (\%) & 1.03 & 2.04 & 7.11 & 1.94 & NS \\
\hline
\end{tabular}

NS: Not significant

a-b Means within rows with varying superscripts differ * $(p<0.05, * * p<0.01)$

'Dietary treatments used in the trial: DW0\% (Control with 0\% duckweed); DW10\% (duckweed inclusion rate at 10\%); DW20\% (duckweed inclusion rate at 20\%)

2SEM: standard error of the mean

${ }^{3}$ Feed Conversion Ratio ( $\mathrm{g}$ feed intake: $\mathrm{g}$ dozen eggs)

${ }^{4}$ Egg Mass = Egg Laying Rate $x$ Egg Weight ( $g$ )

${ }^{5}$ Mortality Rate corrected for both feed intake and feed conversion ratio

\section{Egg quality parameters}

The effect of duckweed supplementation on egg internal and external quality parameters are shown in (Table 4 and 5). No significant differences among the three different treatments were shown in the wet and dry shell \%, wet and dry yolk $\%$ and wet albumin \% contrary to dry albumin \%, which showed an effect $(p<0.05)$ between 7 and 9 weeks and in the whole period of the trial. It decreased with the $10 \%$ supplements of the duckweed $(3.79,3.77 \%)$ compared with the control $(4.12,4.02)$. Yolk Roche color score was highly $(p=0.0001)$ in each period of the trial and through the total period with the different treatments (it increased from 5.71, 6.4 to 6.86). Yolk color increased with increasing the percentage of duckweed supplement in the diet. The blood spots \%
(Table 5) had a significant effect in the 1-3 week period and throughout the total period (1-9 week), (6.13 vs. $0.75,1.15)$, with the $20 \%$ supplement compared with the $10 \%$ and the control groups Grades of eggs were not affected by the dietary supplements, but there was a clear, slight shift in egg grades with the inclusion of the two levels of duckweed in the diet.

\section{DISCUSSION}

\section{Duckweed analysis}

Duckweed samples were analyzed and determined according to (AOAC, 2005) (Table1a), (Shammout \& Zakaria, 2015b). Crude protein was $26 \%$ on $6 \%$ DM, although other researchers reported higher crude protein content (Chowdhury et al., 2000; Akter et 
Table 4 - Egg composition of laying hens fed diets containing 0\%, 10\%, or 20\% duckweed

\begin{tabular}{|c|c|c|c|c|c|c|}
\hline \multirow{2}{*}{ Period } & \multirow{2}{*}{ Parameter Measured } & \multicolumn{5}{|c|}{ Duckweed Inclusion Rate (\%) } \\
\hline & & DW0\% ${ }^{1}$ & DW10\% ${ }^{1}$ & DW20\% ${ }^{1}$ & $\mathrm{SEM}^{2}$ & $p$-Value \\
\hline \multirow[t]{6}{*}{$1-3 w k$} & Wet Shell Percent (\%) & 14.22 & 14.14 & 14.08 & 0.310 & NS \\
\hline & Dry Shell Percent (\%) & 9.73 & 9.70 & 9.68 & 0.132 & NS \\
\hline & Wet Albumen Percent (\%) & 51.62 & 51.64 & 50.56 & 0.773 & NS \\
\hline & Dry Albumen Percent (\%) & 4.02 & 3.91 & 3.86 & 0.085 & NS \\
\hline & Wet Yolk Percent (\%) & 28.15 & 28.02 & 28.51 & 0.382 & NS \\
\hline & Dry Yolk Percent (\%) & 14.73 & 14.77 & 14.69 & 0.239 & NS \\
\hline \multirow[t]{6}{*}{$4-6 w k$} & Wet Shell Percent (\%) & 14.03 & 14.30 & 13.76 & 0.289 & NS \\
\hline & Dry Shell Percent (\%) & 9.76 & 9.87 & 9.60 & 0.146 & NS \\
\hline & Wet Albumen Percent (\%) & 52.49 & 51.22 & 51.92 & 0.770 & NS \\
\hline & Dry Albumen Percent (\%) & 3.89 & 3.70 & 3.83 & 0.089 & NS \\
\hline & Wet Yolk Percent (\%) & 29.13 & 29.10 & 28.91 & 0.438 & NS \\
\hline & Dry Yolk Percent (\%) & 15.75 & 15.42 & 15.47 & 0.299 & NS \\
\hline \multirow[t]{6}{*}{$7-9 w k$} & Wet Shell Percent (\%) & 14.54 & 14.36 & 14.30 & 0.337 & NS \\
\hline & Dry Shell Percent (g) & 9.55 & 9.52 & 9.43 & 0.135 & NS \\
\hline & Wet Albumen Percent (\%) & 53.89 & 51.86 & 53.12 & 0.691 & NS \\
\hline & Dry Albumen Percent (\%) & $4.12^{\mathrm{a}}$ & $3.79^{b}$ & $3.96^{\mathrm{ab}}$ & 0.091 & * \\
\hline & Wet Yolk Percent (\%) & 28.37 & 29.26 & 28.99 & 0.410 & NS \\
\hline & Dry Yolk Percent (\%)) & 14.98 & 15.54 & 15.24 & 0.326 & NS \\
\hline \multirow[t]{6}{*}{$1-9 w k$} & Wet Shell Percent (\%) & 14.26 & 14.26 & 14.06 & 0.250 & NS \\
\hline & Dry Shell Percent (\%) & 9.69 & 9.69 & 9.57 & 0.101 & NS \\
\hline & Wet Albumen Percent (\%) & 52.67 & 51.48 & 51.80 & 0.583 & NS \\
\hline & Dry Albumen Percent (\%) & $4.02^{\mathrm{a}}$ & $3.77^{b}$ & $3.89^{\mathrm{ab}}$ & 0.063 & * \\
\hline & Wet Yolk Percent (\%) & 28.61 & 28.68 & 28.88 & 0.270 & NS \\
\hline & Dry Yolk Percent (\%) & 15.07 & 15.29 & 15.17 & 0.184 & NS \\
\hline
\end{tabular}

a-cMeans within rows with varying superscripts differ * $(p<0.05)$, NS: non significant

${ }^{1}$ Dietary treatments used in the trial: DW0\% (Control with 0\% duckweed); DW10\% (duckweed inclusion rate at 10\%); DW20\% (duckweed inclusion rate at 20\%). ${ }^{2}$ SEM: standard error of the mean.

al. 2011; Anderson et al., 2011). It is evident that CP content of duckweed is variable depending on the species, season, location, environment and nutrient content of water (Khadaker et al., 2007; Chantiratikul et al., 2010), mostly nitrogen concentration (Leng, 1999), water pH (Goopy \& Murray, 2003), different management applied, and if it was collected from a waste lagoon or natural water source, as in this study. Results of crude protein levels indicated that duckweed has good protein \% to complement with soybean meal in satisfying protein requirement of layers, since protein is very important for body tissue synthesis and egg production.

The crude fiber \% in our study was $5.2 \%$, which is considered desirable and suitable for hen feeding since it can be easily digested. Other results reported by different researchers were either lower or higher \% (Leng et al., (1995); Chara et al., (1999) (2.8\%); (9.0\%). While Khanum et al., (2005) reported (12.3\%) and Men et al., (1995) reported more elevated crude fiber $\%(18.7 \%)$, Mbagwu \& Adeniji (1988) demonstrated that duckweed grown under ideal conditions and harvested regularly may have fiber content from 5\% to $15 \%$. Variations of results are due to conditions of growing, harvesting and different duckweed species.

Ether Extract content was 3.1\%; the value found in the present study is higher than that of previous reports (Khan et al., 2002a) that recorded 2.4\% fat, while Khandaker et al., (2007) reported a higher percentage of $(5.06 \%)$. Ether extract $\%$ tended to increase with increasing the level of duckweed in the diet (Table 2). It is possible that this could decrease feed intake and the degree of palatability (De Silva \& Anderson, 1995), which leads to reduction in egg laying rate and less egg quality. So it is more important in future studies to determine the fatty acids profile of this species in order to include duckweed in the poultry rations.

Calcium content in duckweed was $4.3 \%$, which is considered relatively a high percentage compared to SBM (0.27). Becerra et al., (1997) reported 1.1\% compared with $0.4 \%$ SBM of DM. Variation in levels of nutrients is due to the medium in which the plant is grown, as well as the species of the duckweed plant present (Mwale \& Gwaze, 2013). Phosphorus \% of dry matter content was $0.86 \%$, which is comparable to $0.62 \%$ DM for SBM, while Becerra et al., (1997) 
Table 5 - Egg quality parameters of laying hens fed diets containing 0\%, 10\%, or 20\% duckweed

\begin{tabular}{|c|c|c|c|c|c|c|}
\hline \multirow{2}{*}{ Period } & \multirow{2}{*}{ Parameter Measured } & \multicolumn{5}{|c|}{ Duckweed Inclusion Rate (\%) } \\
\hline & & DW0\% ${ }^{1}$ & DW10\% ${ }^{1}$ & DW20\% ${ }^{1}$ & $\mathrm{SEM}^{2}$ & $p$-Value \\
\hline \multirow[t]{8}{*}{$1-3 w k$} & Haugh Units & 77.61 & 79.54 & 82.85 & 2.51 & NS \\
\hline & Yolk Color & $4.75^{c}$ & $5.39^{b}$ & $5.80^{a}$ & 0.138 & $=0.0001$ \\
\hline & Shell Thickness (mm) & 0.338 & 0.330 & 0.331 & 0.0051 & NS \\
\hline & Blood Spots Percent (\%) & $1.03^{b}$ & $1.99^{b}$ & $12.10^{\mathrm{a}}$ & 3.95 & * \\
\hline & Cracked Egg Percent (\%) & 1.03 & 0.77 & 2.08 & 1.32 & NS \\
\hline & Grade AA Egg Percent (\%) & 85.91 & 83.33 & 81.15 & 9.05 & NS \\
\hline & Grade A Egg Percent (\%) & 8.23 & 14.34 & 16.32 & 7.92 & NS \\
\hline & Grade B Egg Percent (\%) & 8.33 & 11.11 & 2.76 & 5.46 & NS \\
\hline \multirow[t]{8}{*}{$4-6 w k$} & Haugh Units & 85.04 & 84.01 & 79.37 & 2.61 & NS \\
\hline & Yolk Color & $5.82^{b}$ & $6.70^{\mathrm{b}}$ & $6.91^{\mathrm{a}}$ & 0.175 & $=0.0001$ \\
\hline & Shell Thickness (mm) & 0.349 & 0.352 & 0.342 & 0.0047 & NS \\
\hline & Blood Spots Percent (\%) & 1.18 & 0.65 & 2.57 & 0.861 & NS \\
\hline & Cracked Egg Percent (\%) & 1.40 & 1.64 & 2.31 & 0.828 & NS \\
\hline & Grade AA Egg Percent (\%) & 97.22 & 88.88 & 77.78 & 6.45 & NS \\
\hline & Grade A Egg Percent (\%) & 2.78 & 5.56 & 11.11 & 4.63 & NS \\
\hline & Grade B Egg Percent (\%) & 1.63 & 3.92 & 11.11 & 2.98 NS & \\
\hline \multirow[t]{8}{*}{$7-9 w k$} & Haugh Units & 86.20 & 86.67 & 82.93 & 2.01 & NS \\
\hline & Yolk Color & $6.52^{c}$ & $7.20^{\mathrm{b}}$ & $7.86^{a}$ & 0.160 & $=0.0001$ \\
\hline & Shell Thickness (mm) & 0.342 & 0.344 & 0.343 & 0.0055 & NS \\
\hline & Blood Spots Percent (\%) & 0.25 & 0.53 & 3.76 & $1.11 \mathrm{NS}$ & \\
\hline & Cracked Egg Percent (\%) & 0.96 & 1.32 & 1.74 & 0.693 & NS \\
\hline & Grade AA Egg Percent (\%) & 88.89 & 91.66 & 83.33 & 6.46 & NS \\
\hline & Grade A Egg Percent (\%) & 5.64 & 6.81 & 4.21 & 3.98 & NS \\
\hline & Grade B Egg Percent (\%) & 6.34 & 4.04 & 11.84 & 4.59 & NS \\
\hline \multirow[t]{8}{*}{$1-9 w k$} & Haugh Units & 82.60 & 83.83 & 81.72 & 1.47 & NS \\
\hline & Yolk Color & $5.71^{c}$ & $6.41^{\mathrm{b}}$ & $6.86^{a}$ & 0.094 & $=0.0001$ \\
\hline & Shell Thickness (mm) & 0.343 & 0.343 & 0.339 & 0.0032 & NS \\
\hline & Blood Spots Percent (\%) & $0.75^{b}$ & $1.15^{b}$ & $6.13^{a}$ & 1.52 & * \\
\hline & Cracked Egg Percent (\%) & 1.13 & 1.26 & 2.03 & 0.765 & NS \\
\hline & Grade AA Egg Percent (\%) & 87.94 & 87.87 & 80.66 & 5.89 & NS \\
\hline & Grade A Egg Percent (\%) & 5.49 & 8.67 & 10.85 & 3.21 & NS \\
\hline & Grade B Egg Percent (\%) & 5.22 & 5.90 & 9.25 & 2.60 & NS \\
\hline
\end{tabular}

a-cMeans within rows with varying superscripts differ * $(P<0.05),(P=0.0001$, NS: non significant)

' Dietary treatments used in the trial: DW0\% (Control with 0\% duckweed); DW10\% (duckweed inclusion rate at 10\%); DW20\% (duckweed inclusion rate at 20\%) ${ }^{2}$ SEM: standard error of the mean.

and Men et al., (1996) reported 0.5\% P content in DM. Duckweed is able to accumulate up to $1.5 \%$ of its weight as phosphorus in nutrient-rich waters, which is considered normal (Leng, 1999). Chlorine $\%$ is higher than SBM; this is related to the quality of the water where this species is grown, which is within the permitted levels. The nutritional content of duckweed is probably more dependent on the mineral concentrations of the growth medium than on the species or their geographic location. It is important to evaluate the mineral profile of the plant before diet formulation because of the high mineral content which might lead to a detrimental effect.

\section{Body performance and egg production}

The effect of supplementing diet with duckweed to replace percentages of soybean meal is presented in
(Table 3). There were no significant differences in body weight and feed conversion ratio among treatments during the different phases. The non-significant results for change in body weight agreed well with Hamid et al., (1993) who fed Lemna meal to ducklings and observed minimum variations in weight gain; Aktler et al., (2011) recorded same results when Lemna minor meal was used in the diet of laying hen. However, feed intake was decreased $(p=0.002)$ by duckweed supplementation up to $20 \%$ replacement of soybean meal, although the crude fiber content in the diet used in this trial was not high (3.11\%). The highest feed intake was for the control and the 10\% duckweed through the different periods of the trial. These results are inconsistent with Haustein et al., (1990) who reported significant differences in feed consumption among the control, the Lemna 15\% $(p<0.02)$ group 
and the Wolffia 15\% $(p<0.03)$ group, where the Lemna group showed a slight decrease in feed intake. Chantiratikul et al., (2010) also reported reduction of feed intake $(p<0.05)$ when CP was totally replaced by CP from Wolffia meal or when using $12 \%$ dietary Wolffia meal in the diet. Aktler et al., (2011) also reported no significant difference in feed intake when Lemna minor meal was added to the laying diet. The higher percentage of duckweed in diets (20\%) might have suppressed the appetite due to unspecified antinutritional factors or compounds which likely to be inhibiting digestion and metabolism (Goopy \& Murray, 2003) or due to differences present in digestible protein content. Feed conversion was better numerically, with the higher concentration of the duckweed during the total period of the trial due to the decrease in feed intake and consequently lower body weight. The results are congruent with (Haustein et al., 1990 and Hamid et al., 1993). This result might be explained by the presence of some type of anti-nutritional factors that limits intake and growth when fed at high levels (Goopy \& Murray 2003).

Mortality was $(p<0.01)$ between $7-9$ weeks of the study with the replacement of $20 \%$, but it was corrected in the whole period without any effect between treatments; mortality within treatments ranged from $1.03 \%, 2.04 \%, 7.11 \%$ respectively. This implies that $20 \%$ replacement of SBM with duckweed had an adverse effect on layers since it increased the mortality percentage, although birds were reared in cages under good management conditions. The same results were recorded by Hassan and Edwards (1992), who cited mortality rates in excess of $80 \%$ at the highest feeding rate when they included $L$. perpusilla and S. polyrrhiza up to $30 \mathrm{~g} \mathrm{DMkg}-1$ in the diet of Nile tilapia, where these species have $23 \% \mathrm{CP}$, in contrast with Faskin et al., (1999), who used (50\% CP) and recorded no significant increase in mortality, compared to the control group, even with $100 \%$ substitution. Previous reports by Suppadit et al., (2012), who used Wolffia arrhiza meal as a substitute for soybean meal showed no significant differences in the mortality of laying quails. It may be that as the protein component of plant material decreased the exposure to antinutritional elements in the feed increase and thus results in negative growth responses (Goopy and Murray, 2003). Inconsistencies among results were due to species differences of duckweed and birds used, or other environmental conditions of the different trials.

Egg laying rate\% was $(p<0.05)$ reduced in birds that received the $20 \%$ duckweed, while those received the 10\% duckweed produced eggs at a rate close to the control birds (Table 3). During the 7-9weeks $(p=0.001)$, and during the whole period of the trial $(p<0.01)$, laying rate decreased significantly in the $20 \%$ DW group. The low rate of egg production of this particular group might be due to decrease in feed intake, affecting body weight and leading to a decrease in egg production (Aktler et al., 2011).

Egg mass output was comparable with the 10\% duckweed group, but it was reduced $(p<0.05$, 0.01 ) with the higher level, probably due to low rate of production. In turn, this is a reflection of feed consumption that decreased with the higher percentage of duckweed that might have some antinutritional factors that depress bioavailability and utilization of nutrients in the digestive tract and affect performance. The absence of a clear reduction in egg weight suggests that body reserves were mobilized to maintain egg production (Paterson et al., 2000) since there was a slight decrease in body weight.

\section{Egg quality}

External and internal egg quality characteristics are shown in Tables 4 and 5 . Dry albumin \% (Table 4) was $(p<0.05)$ with the $10 \%$ duckweed compared to control and $20 \%$, in contrast to findings reported by Aktler et al., (2011). Haugh unit score, the key indicator of interior egg quality was not influenced by diets supplements, but it decreased numerically with increasing level of duckweed. Highly improvement $(p=0.0001)$ of yolk color with increasing level of duckweed in the diet indicates that Lemna gibba species contains a sufficient amount of pigments to give attractive, darker yolks. This agrees with (O'Neil et al., 1996; Nolan et al., 1997; Chantiratikul et al., 2010; Aktler et al., 2011; Anderson et al., 2011; and Suppadit, 2012). Haustein et al., (1990) without referring to yolk color score, reported increased pigmentation $(p<0.01)$ when Lemna gibba $(150 \mathrm{~g} / \mathrm{kg})$ and Wolffia $(150 \mathrm{~g} / \mathrm{kg}$ ) species were included in the diet. Duckweed has high concentrations of pigments, particularly beta carotene (120-627.2 mg/kg) and xanthophylls (261-1000mg/ kg) (Haustein et al., 1990; Skillcorn et al., 1993; Hanczakowski et al., 1995). The high concentrations are probably due to the anatomical structure of this plant and the high contribution of leaves to its total biomass (Hanczakowski et al., 1995; Chantiratikul et al., 2010b) Pigmentation is an important attribute that adds economic value of duckweed as dietary ingredients since it is commercially desirable. Blood spots were $(p<0.05)$ in the $1-3$ weeks period and 
through the total period (1-9 weeks), and it recorded high value with the $20 \%$ supplement compared to the other two groups $(6.13$ vs.0.75, 1.15). Blood spots are usually formed due to tissue irregularity in the hen causing a small amount of blood to be deposited in the egg. It usually occurs due to vitamin A or K deficiency, but since this was not present in the diet and not seen in other groups, then it might be due to stress as a result of high amount of the duckweed inclusion levels in the diet USDA (2000). Shell thickness and cracked egg \% did not differ between treatments, since there was no difference in Ca\% between diets, which affect the shell strength, and this reflects the insignificant results of egg weight within the different treatments.

As for the impact of feeding duckweed on USDA egg grades, there were no effects on the percentages of grade AA, A and B, contrary to results reported by Anderson et al., (2011).

\section{Economic assessments}

The price of feed was highest for the control group (243.42 JD/ton feed) (Table 2), and it tended to decrease with increasing the level of duckweed substitution. Production cost calculation was based only on feed cost. Duckweed is not a conventional feed, and its price was only estimated for collection and drying. Since results indicated that $20 \%$ duckweed in the diet did not improve performance and it decreased egg production, therefore the comparison is between the control group and the 10\% supplement with DW group, which gave 5JD/ton profit. If it is assumed that on the average a feed processing unit produces 200 metric tons of feed/day: $200 \times 30$ days $=6000$ metric tons $/$ month. This gives $6000 \times 5 \mathrm{JD}=30.000 \mathrm{JD}$. This indicates the profit that will be gained by using duckweed to replace certain percentages of expensive soybean meal.

\section{CONCLUSIONS}

Duckweed by knowing the quality of water where it grows in and its chemical analysis, can be used as a source of protein and pigment to replace $10 \%$ of SBM in the laying hens' ration with no harmful effect on production performance and egg quality, while increasing the level up to $20 \%$ decreased the reproductive performance. The advantages from feeding duckweed to laying hens lies in its use as a source of pigment to make eggs more attractive to consumers; also a very good source for minerals besides decreasing feed cost. Duckweed can represent an important dietary protein source to replace SBM, especially in countries like Jordan where imported SBM is expensive, and corn and soybean meal are the key ingredients in poultry feeds. Drying, especially to levels where it can be preserved, represents the only major cost in terms of labor and energy. Since this trial is the first in Jordan to use this species, further research is needed to evaluate other percentages of duckweed in diets of laying hens. Environment related to growth and quality investigation is very important to establish the economic value of this feed for use in future formulations.

\section{CONFLICT OF INTEREST}

No conflict of interest between authors.

\section{ACKNOWLEDGEMENTS}

The research was supported by Abdul-Hameed Shoman Foundation-Abdul Hameed Shoman Fund for Supporting Scientific Research, Amman-Jordan.

\section{REFERENCES}

Abudabos AM. Effect of enzymes supplementation and wheat middlings as an alternative to corn on laying hen performance. Italian Journal of Animal Science 2011;10(4):254-259.

Aktler M, Chowdhury SD, Akter Y, Khatun MA. Effect of duckweed (Lemna minor) meal in the diet of laying hen and their performance. Bangladesh Research Publication Journal 2011;5(3);252-261.

Al-Esawi DM. List of Jordan vascular plant. Mitteilungen der Botanischen Staatssammlung Munchen 1982;18:79-182.

Anderson KE, LowmanZ, Stomp A, ChangJ. Duckweed as a feed ingredient in laying hen diets and its effect on egg production and composition. International Journal of Poultry Science 2011;10(1):4-7.

AOAC - Association of Official Analytical Chemists. Official methods of analysis. $18^{\text {th }}$ ed. Washington; 2006.

Becerra M, Ogle B, PrestonTR. Effect of replacing whole boiled soybeans with duckweed (Lemna sp) in the diets of growing ducks. Livestock Research for Rural Development 1995;7(3)

Chantiratikul A, Chinrasn O, Chantiratikul P, Sangdee A, Maneechote U, Bunchasak $C$. Effect of replacement of protein from soybean meal with protein from Wolffia meal (Wolffiaglobosa (L).Wimm), on performance and egg production in laying hens. Journal of Poultry Science 2010b;9(3):283-287.

Chara J, Pedraza G, Conde N. The productive water decontamination system: a tool for protecting water resources in the tropics. Livestock Research for Rural Development 1999;11(1) 25-35.

Chowdhury SA, Sultana N, Huque KS, Huque QME. Manure based duckweed production in shallow sink; effect of genera on biomass and nutrient yield of duckweed under the same nutritional and management conditions. Asian-Australasian Journal of Animal Science 2000;13(5):686-693. 
Faskin EA. Nutrient quality of leaf protein concentrates produced from water fern (Azolla Africana Desv) and duckweed (SpirodelaPolyrrhiza L. Scheiden). Bioresource Technology 1999;62:185-187.

Goopy JP, Murray PJ. A review on the role of duckweed in nutrient reclamation and as a source of animal feed. Asian Australasian Journal of Animal Science 2003;16:297-305.

Hamid MA, Chowdhury SD, RazzakMA, Roy CR. Effects of feeding an aquatic weed Lemnatrisulaca as partial replacement of fish meal on the performance of growing ducklings. Journal of Science of Food and Agriculture 1993;63:137-139.

Hanczakowski P, Szymczyk B, Wawrzynski M. Composition and nutritive value of sewage-grow duckweed (Lemna minor L.) for rats. Animal Feed Science and Technology 1995;52:339-343.

Hassan MS, Edwards P. Evaluation of duckweed (Lemna perpusilla and Spirodellapolyrrhiza) as feed for NileTilapia (Oreochromis niloticus). Aquaculture 1992;104:315-26.

Haustein AT, Gilman RH, Skilicorn PW, Haman $\mathrm{H}$, GuevaraV, Verara, $\mathrm{V}$, et al. Performance of broiler chickens fed diets containing duckweed (Lemna gibba).). Journal of Agricultural Science 1994;122:285-289.

Haustein AT, Gilman RH, Skilicorn PW, Haman H, GuevaraV, VeraraV, et al. Compensatory growth in broiler chicks fed on (Lemna gibba). British Journal of Nutrition 1992;68:329-335.

Haustein AT, Gilman RH, Skillicorn PW, Vergara V, Guevara V, Gastanaduy A. Duckweed, a useful strategy for feeding chickens: performance of layers fed with sewage- grown Lemnacea species. Poultry Science 1990;69(11):1835-1844.

Hillman WS, Cullay DD. The use of duckweed. American Scientists 1978;66:442-448

Islam KMS, Shahjalal M, Tareque AMM, Howlider MAR. Complete replacement of dietary fishmeal by duckweed and soya bean meal on the performance of broilers. Asian-Australasian Journal of Animal Science 1997;10:629-634.

Jordanian Standard. Jordanian reclaimed waste water standard [JS893/2006]. Amman; 2006.

Khan MJ, Steingass $H$, Drochner W. Evaluation of some aquatic plants from Bangladesh through mineral composition, In Vitro gas production and in situ degradation measurements. Asian-Australasian Journal of Animal Science 2002a;15(4):537-542.

Khandaker T, Khan MJ, Shahjalal M, Rahman MM. Use of duckweed (Lemnaperpusilla) as a protein source feed item in the diet of semiscavenging Jinding layer ducks. Journal of Poultry Science 2007;44:314321.

Khanum J, Chwalibog A, Huque KS. Study of digestibility and feeding systems of duckweed in growing ducks. Livestock Research for Rural Development 2005;17(10)

Leng RA, Stambolie JH, Bell R. Duckweed-a potential high-protein feed resource for domestic animals and fish. Livestock Research for Rural Development 1995;7(1):103-114.

Leng RA. Duckweed-A tiny aquatic plant with enormous potential for agriculture and environment. Phenom Penh: Animal Production and Health Division, University of Tropical Agriculture Foundation; 1999. p.108.

Mbagwu IG, Adeniji HA. The nutrient content of duckweed Lemna paucieostata Hegelm in the Kainji Lake area, Nigeria. Aquatic Botanical 1988;29:357-366.

Men BX, Ogle B, Lindberg JE. Use of duckweed as a protein supplement for growing ducks. Asian-Australasian Journal of Animal Science 2001;14:1741-1746.
Men BX, Olge B, Preston TR. Use of duckweed (Lemnaspp) as replacement for soybean meal in a basal diet of broken rice for fattening ducks. Livestock Research for Rural Development 1995;8:14-19

Ministry of Agriculture. The annual report of the animal production department. Amman (JOR): Ministry of Agriculture; 2016.

Mwale M, Gwaze FR. Characteristics of duckweed and its potential as feed source for chickens reared for meat production: A review. Scientific Research and Essays, Academic Journal 2013;8(18):689-697.

Nolan JV, Bell RE, Thomson E, Bremner D, Ball W. Duckweed (Spirodela punctata) as a protein and pigment source in diets for layers. Proceedings of theAustralian Poultry Science 1997;(9):166-170.

NRC-National Research Council. Nutrient requirements of poultry. $9^{\text {th }}$ ed Washington: National Academy Press; 1994

O'Neil PJ, Nolan JV, Thomson E. Duckweed as an alternative to soybean meal in diets for high producing layers. Proceedings Australian Poultry Science Symposium 1996;8:123-127

Paterson RT, Roothaert RL, Kiruiro E. The feeding of leaf meal of Callindra calothyrsus to laying hens.Tropical Animal Health and Production 2000:32:51-61

Rodriguez L, Preston TR. Observations on scavenging local (Indigenous) and Tam Hoang (exotic) chickens given free access duckweed (Lemnacea) offered alone or mixed with rice bran. Livestock Research for Rural Development 1999;11(1)

Samnang $H$. Duckweed versus ground soya bean as supplement for scavenging native chickens in an integrated farming system. Livestock Research for Rural Development 1999;11(1)

SAS- Statistical Analysis System. User's guide: statistics. Version 9.4 Cary; 2013.

Shammout MW, Oran S, FayyadM. The application of duckweed (Lemna $S p$.$) in wastewater treatment in Jordan. International Journal of$ Environmental Pollution 2008;33(1): 110-120.

Shammout MW, Zakaria H. Water lentils (duckweed) in Jordan irrigation ponds as a natural water bioremediation agent and protein source for broilers. Ecological Engineering 2015b;83:71- 77

Shammout MW, Zakaria $\mathrm{H}$. Water quality and growth trend of aquatic plant duckweed: management and benefits. Proceedings of the International Conference on Environment Engineering and Computer Application 2014 Dec 25-26; Hong Kong; 2015a. p.85-87.

Shammout MW, Zakaria H. Wild water lentils plant (Duckweed, Lemna sp.). Nutrients removal of Jordan's ponds. Section 3, Environmental science and technology. Witt Transactions on the Built Environment 2014;145: 525-529.

Silva SS, Anderson TA. Fish nutrition in aquaculture. London: Chapman and Hall; 1995. v.1.

Skillicorn P, Spira W, Journey W. Duckweed aquaculture a new aquatic farming system for developing countries. Washington: The World Bank; 1993. p.68.

Suppadit T, Jaturasitha S, Sunthorn N, Poungsuk P. Dietary Wolffia arrhiza meal as a substitute for soybean meal: its effects on the productive performance and egg quality of laying Japanese quails. Tropical Animal Health and Production 2012;44(7):1479-1486.

USDA. Egg: grading manual [agricultural handbook, 75]. Washington: U.S Departament of Agriculture; 2000 